University of Nebraska - Lincoln

DigitalCommons@University of Nebraska - Lincoln

Faculty Publications in Food Science and Technology

Food Science and Technology Department

2011

\title{
Environment and Hybrid Influences on Rapid-Visco-Analysis Flour Properties of Food-Grade Grain Sorghum
}

Joni K. Griess

University of Nebraska-Lincoln

Stephen C. Mason

University of Nebraska-Lincoln, smason1@unl.edu

David S. Jackson

University of Nebraska-Lincoln, djackson1@unl.edu

Tom D. Galusha

University of Nebraska-Lincoln, tgalusha1@unl.edu

Jeffrey F. Pedersen

USDA-ARS Grain, Forage and Bioenergy Research Unit, jpedersen1@unl.edu

See next page for additional authors

Follow this and additional works at: https://digitalcommons.unl.edu/foodsciefacpub

Part of the Food Science Commons

Griess, Joni K.; Mason, Stephen C.; Jackson, David S.; Galusha, Tom D.; Pedersen, Jeffrey F.; and Yaseen, Muhammad, "Environment and Hybrid Influences on Rapid-Visco-Analysis Flour Properties of Food-Grade Grain Sorghum" (2011). Faculty Publications in Food Science and Technology. 112.

https://digitalcommons.unl.edu/foodsciefacpub/112

This Article is brought to you for free and open access by the Food Science and Technology Department at DigitalCommons@University of Nebraska - Lincoln. It has been accepted for inclusion in Faculty Publications in Food Science and Technology by an authorized administrator of DigitalCommons@University of Nebraska - Lincoln. 


\section{Authors}

Joni K. Griess, Stephen C. Mason, David S. Jackson, Tom D. Galusha, Jeffrey F. Pedersen, and Muhammad Yaseen 


\title{
Environment and Hybrid Influences on Rapid-Visco-Analysis Flour Properties of Food-Grade Grain Sorghum
}

\author{
Joni K. Griess, Stephen C. Mason,^ David S. Jackson, Tomie D. Galusha, \\ Jeffrey F. Pedersen, and Muhammad Yaseen
}

\begin{abstract}
Grain processors would benefit from information about the production environment and the influences of the sorghum [Sorghum bicolor (L.) Moench] hybrid on food-grade flour properties. The objective of this study was to determine the effects of environment and hybrid on rapid-visco-analysis (RVA) flour properties of commercially available food-grade sorghum. A randomized complete block experiment was planted in 12 environments, which included the 2004 and 2005 growing seasons and irrigated and dryland water regimes in eastern, central, and west central Nebraska, and a dryland, low- $\mathrm{N}$ environment in eastern Nebraska. The environment accounted for $71-85 \%$ of the total variation in RVA parameters, while the hybrid accounted for $11-23 \%$ and the environmentby-hybrid interaction, 1-3\%. Unfortunately, the results of this experiment suggest that it is difficult to predict the effect that environment will have on resulting sorghum-flour parameters. Although of secondary importance in terms of total variation in sorghum-flour RVA properties, the choice of hybrid predictably and significantly contributes to sorghum-starch viscosity properties. Food-grade hybrids were grouped based on viscosity properties into those best suited for dry-mill and alkaline-cooked products (Asgrow Orbit; Sorghum Partners NK1486) and those best suited for porridge, consumable alcohol, and ethanol production (Kelly Green Seeds KG6902; NC+ Hybrids 7W92; Asgrow Eclipse; and Fontanelle W-1000). These results were consistent with those previously reported for grain density.
\end{abstract}

J.K. Griess, S.C. Mason, and T.D. Galusha, Dep. of Agronomy and Horticulture, Univ. of Nebraska, Lincoln, NE 68583; D.S. Jackson, Dep. of Food Science and Technology, Univ. of Nebraska, Lincoln, NE 68583; J.F. Pedersen, USDA-ARS Grain, Forage and Bioenergy Research Unit, 314 Biochem, Lincoln, NE 68583; M. Yaseen, Dep. of Statistics, Univ. of Nebraska, Lincoln, NE 68583. Joint contribution of the Dep. of Agronomy and Horticulture and Agricultural Research Division, Univ. of Nebraska, and USDA-ARS Grain, Forage and Bioenergy Research Unit, with partial funding from the Nebraska Grain Sorghum Board and INTSORMIL, project DAN 1254-G-0021, funded by the United States Agency for International Development, Washington, DC. The use of trade, firm, or corporation names in this publication (or page) is for the information and convenience of the reader. Such use does not constitute an official endorsement or approval by the Univ. of Nebraska or the USDA Agricultural Research Service of any product or service to the exclusion of others that may be suitable. Received 20 Oct. 2010. `Corresponding author (smason1@unl.edu).

Abbreviations: RVA, rapid visco analysis.

Crain sorghum [Sorghum bicolor (L.) Moench] is an important Jrain crop because of its drought tolerance (Hattendorf et al., 1988), high nutrient-use efficiency (Maranville et al., 1980), and multiple end uses, especially for livestock feed (Kriegshauser et al., 2006) and ethanol production (Wu et al., 2007; Zhao et al., 2008). Food-grade grain sorghum, which has a white grain and tan glumes, has recently become of interest for flour substitution (Rooney and Awika, 2005), brewing (Figueroa et al., 1995), and extruded snack foods (Rooney, 1996) and as a partial replacement for maize (Zea mays L.) in tortilla production in Central America (Almeida-Dominguez et al., 1997). Sorghum flour is also gluten free, making it a desirable food product for humans with gluten intolerance (Fasano

Published in Crop Sci. 51:1757-1766 (2011).

doi: $10.2135 /$ cropsci2010.10.0604

Published online 10 May 2011.

(C) Crop Science Society of America | 5585 Guilford Rd., Madison, WI 53711 USA

All rights reserved. No part of this periodical may be reproduced or transmitted in any form or by any means, electronic or mechanical, including photocopying, recording, or any information storage and retrieval system, without permission in writing from the publisher. Permission for printing and for reprinting the material contained herein has been obtained by the publisher. 
and Catassi, 2001), and many hybrids have high levels of antioxidants and dietary fiber (Rooney and Awika, 2005).

Little research has been conducted on comparing the influences of the environment and agronomic practice on the grain quality of sorghum hybrids. In a companion study, the environment was found to have the largest effect on variation in grain yield, kernel mass, kernel density, and kernel composition; the hybrid to have an intermediate effect; and the environment-by-hybrid interaction to have minor importance, accounting for less than $2 \%$ of the total variation (Griess et al., 2010). This research indicated that dryland production environments with a nonlimiting $\mathrm{N}$ supply produced dense sorghum kernels with high protein and low starch concentrations, as also reported by Johnson et al. (2010), Taylor et al. (1997), and Kaye et al. (2007), whereas irrigated production environments produced softer grain. Asgrow Orbit and ICRISAT Macia produced the densest kernels with high protein and low starch concentrations, whereas Kelly Green Seeds KG6902; NC+ Hybrids 7W92; and Fontanelle W-1000 produced soft kernels with low protein and high starch concentrations (Griess et al., 2010).

Rapid visco analysis (RVA) of starch is a method that relates biochemical components to hardness (Fox and Manley, 2009), which has been related to maize density (Almeida-Dominguez et al., 1997; Narváez-González et al., 2007; Barbosa Pinto et al., 2009). This method measures the viscosity developed during hydration and subsequent gelatinization of starch granules during heating and stirring in excess water (Almeida-Dominguez et al., 1997), including the pasting temperature when gelatinization begins and the peak viscosity at full gelatinization. When held at the maximum temperature and stirred, the starch molecules become oriented (shear thinning), and the viscosity declines to the trough viscosity (holding strength). The difference between peak and trough viscosity is termed breakdown viscosity, and a low value indicates shear-force stability under heated conditions. As the temperature is lowered, the viscosity increases to a final viscosity, with the difference between the final and trough viscosities being termed the setback viscosity. These starch-viscosity properties help predict the functionality of food products. High peak, final, and setback viscosities have been associated with high ethanol yield from sorghum grain (Zhao et al., 2008); high pasting temperatures with the need for intensive cooking to produce high consumable alcohol yields (Agu et al., 2006); and low peak viscosity with softer endosperm, greater expansion of starch during cooking, and production of less-stiff porridges (Taylor et al., 1997). Rapid visco analysis of starch has been used to determine the effect of processing on tortilla quality (Gomez et al., 1992); the pasting characteristics of maize, wheat (Triticum aestivum L.), and potato (Solanum tuberosum L.) starch (Deffenbaugh and Walker, 1989); and the association of high peak and final viscosity with the quality of noodles made from sorghum grain (Beta and Corke, 2001); and it was used to assess genetic diversity in South African sorghum landraces for starch properties (Beta et al., 2001). Ragaee and Abdel-Aal (2006) tested whole sorghum flours and found higher paste stabilities than for barley (Hordeum vulgare L.), pearl millet [Pennisetum glaucum (L.) R. Br.], and rye (Secale cereal L.), indicating sorghum grain's high potential as an ingredient in food products that are exposed to high temperatures and mechanical stirring. Most studies have used RVA to study sorghum-kernel properties and/or genetic differences (Beta and Corke, 2001), but none have studied the joint influence of the production environment and sorghum hybrid on starch properties. The objective of this research was to determine the effects of the environment and hybrid on RVA flour properties of modern food-grade grain sorghum hybrids.

\section{MATERIALS AND METHODS}

Field experiments were conducted in 12 Nebraska environments, with each location-year combination being considered an environment (Table 1). The environments were selected to be representative of an array of environments typical of sorghum production in Nebraska. Experiments in eastern Nebraska were conducted at the University of Nebraska Agricultural Research and Development Center near Mead, NE under furrow irrigation, dryland, and dryland-with-low-N environments in 2004 and 2005. Experiments in central Nebraska were conducted under dryland and furrow-irrigated environments at the South Central Agricultural Laboratory, near Clay Center, NE and in a farmer's dryland field at Hebron, NE in 2004 and 2005. In 2005, a dryland location in west-central Nebraska was added near Orleans, NE.

All commercial food-grade sorghum hybrids available in 2004 and adapted to Nebraska were included in the experiment. Nine commercial food-grade hybrids and six commercial non-food-grade hybrids with maturity range classifications similar to the food-grade hybrids were used as checks (Table 2). In addition, Macia, a white-grain, tan-plant sorghum variety from Africa was used as a high-grain-quality check (Dlamini et al., 2007).

The experiment was conducted as a randomized complete block experiment with three replications in each environment. Monthly average temperatures and precipitation totals for each environment and detailed field experimentation procedures are presented in Griess et al. (2010). The environments and hybrids were considered fixed effects in the model, while block effects within an environment were considered random. Preplanned single-degree-of-freedom contrasts based on the experimental design, some being orthogonal and others not, and LSDs ( $p=$ 0.05) were used to separate the main-effect means for all parameters measured, and Pearson correlation coefficients were calculated to determine the relationship among yield, kernel mass, density parameters, protein and starch concentrations, and RVA parameters. The effects of environment-by-hybrid interactions were studied by partitioning sums of squares for food-grade and nonfood-grade hybrids and the hybrid maturity effects, which were tested by ANOVA, and then graphing on environmental means to assist with interpretation (Budak et al., 1995; Griess et al., 2010).

Pasting properties of finely ground sorghum flour were determined using RVA (RVA-4, Newport Scientific, Warriewood, 
Table 1. Environment influence on sorghum protein and starch concentrations and starch viscosity properties (averaged over 16 hybrids).

\begin{tabular}{|c|c|c|c|c|c|c|c|c|c|}
\hline \multirow[b]{2}{*}{ Environment } & \multirow[b]{2}{*}{ Protein } & \multirow[b]{2}{*}{ Starch } & \multicolumn{5}{|c|}{ Viscosity } & \multirow[b]{2}{*}{ Peak time } & \multirow{2}{*}{$\begin{array}{c}\text { Pasting } \\
\text { temperature }\end{array}$} \\
\hline & & & Peak & Trough & Breakdown & Final & Setback & & \\
\hline & $g$ & -1 & 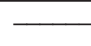 & 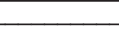 & $\mathrm{CP}$ & 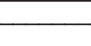 & 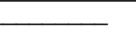 & $\min$ & ${ }^{\circ} \mathrm{C}$ \\
\hline \multicolumn{10}{|l|}{2004} \\
\hline Mead dryland low-N & 98 & 640 & 1455 & 878 & 577 & 1360 & 2238 & 9.91 & 83.98 \\
\hline Clay Center dryland & 112 & 690 & 1281 & 963 & 319 & 1804 & 2766 & 10.67 & 86.27 \\
\hline Hebron dryland & 98 & 704 & 1888 & 1306 & 583 & 2080 & 3386 & 10.27 & 84.60 \\
\hline Mead irrigated & 99 & 704 & 1574 & 1245 & 328 & 2023 & 3269 & 10.77 & 88.11 \\
\hline Clay Center irrigated & 99 & 699 & 1785 & 1365 & 420 & 2462 & 3827 & 10.76 & 87.65 \\
\hline \multicolumn{10}{|l|}{2005} \\
\hline Mead dryland low-N & 77 & 714 & 1831 & 1248 & 583 & 2135 & 3383 & 10.37 & 83.32 \\
\hline Clay Center dryland & 99 & 701 & 1449 & 1173 & 276 & 2514 & 3687 & 10.92 & 87.64 \\
\hline Mead dryland & 109 & 701 & 1212 & 1163 & 249 & 2510 & 3673 & 10.93 & 87.21 \\
\hline Hebron dryland & 101 & 695 & 1475 & 1230 & 244 & 2519 & 3749 & 11.09 & 88.17 \\
\hline Orleans dryland & 125 & 688 & 1040 & 924 & 116 & 1597 & 2521 & 11.19 & 86.32 \\
\hline Mead irrigated & 108 & 698 & 1419 & 1245 & 174 & 2003 & 3249 & 11.48 & 89.59 \\
\hline Clay Center irrigated & 111 & 707 & 1394 & 1121 & 273 & 2407 & 3527 & 10.81 & 87.53 \\
\hline $\operatorname{LSD}(0.05)$ & 6 & 5 & 142 & 84 & 76 & 227 & 184 & 0.17 & 1.02 \\
\hline
\end{tabular}

Australia) as described by Walker et al. (1988). Whole-grain-flour samples of $3.5 \mathrm{~g}$ were ground using a Perten Laboratory Mill 3100 (Perten Instruments, Stockholm, Sweden) using a 1-mm screen. Samples were corrected to $140 \mathrm{~g} \mathrm{~kg}^{-1}$ moisture concentration and added to $25 \mathrm{~mL}$ water in an aluminum cup with a plastic paddle. Stirring at $500 \mathrm{rpm}$ for $8 \mathrm{~s}$ by the RVA-4 ensured that flour was thoroughly slurried with water at the beginning of the test. The constants for RVA were stirring speed, paddle type and clearance, sample volume, and heating-and-cooling profile. The viscosity of the flour paste was continuously measured throughout the test in centipoise $(\mathrm{cP})$ units. Rapid-viscoanalysis pasting curves indicating the viscosity measurements were recorded by Thermocline version 2.2 software (Newport Scientific). The five viscosities recorded for analysis of whole sorghum flour were peak viscosity, the maximum viscosity of hot paste; holding viscosity, the minimum hot-paste viscosity at the bottom of the "trough"; breakdown viscosity (peak viscosity - holding viscosity); final viscosity, the viscosity at the end of the test; and setback viscosity (final viscosity - holding viscosity). Two other measurements recorded were peak time, the time when peak viscosity occurred, and pasting temperature, the temperature when viscosity first increased by at least $25 \mathrm{cP}$ over a 20-s period. Fifteen-gram samples were evaluated for protein (Padmore, 1990) and starch (Hall, 2001) concentrations by Ward Laboratory, Kearney, NE. Although the protein and starch concentrations were previously presented in Griess et al. (2010), they are presented again in this paper because of their importance in interpreting RVA results and for the readers' convenience.

\section{RESULTS AND DISCUSSION}

\section{Correlation Analysis}

Correlation among RVA parameters were generally significant, with peak viscosity being correlated with all other parameters $(R=0.42-0.84$; Table 3$)$. Grain yield and kernel mass from Griess et al. (2010) had moderate correlations
Table 2. Characteristics of grain sorghum hybrids used in this study.

\begin{tabular}{lc}
\hline \multicolumn{1}{c}{ Hybrid } & Maturity class $^{\dagger}$ \\
\hline Food-grade & \\
Sorghum Partners NK 8828 & Late \\
Asgrow Eclipse & Medium \\
Asgrow Orbit & Medium \\
Kelly Green Seed KG6902 & Late \\
Fontanelle W-1000 & Medium \\
NC+ Hybrids 7W92 & Medium \\
Sorghum Partners NK 1486 & Medium \\
Dekalb 44-41 & Medium \\
Mycogen 14665 & Late \\
Food-grade check & \\
Macia & Medium \\
Non-food-grade (checks) & \\
Dekalb 54-00 & Late \\
Dekalb 42-20 & Medium \\
Dekalb 53-11 & Medium \\
NC+ Hybrids 6C69 & Medium \\
Pioneer 84Y00 & Late \\
Mycogen 3696 & Medium \\
\hline
\end{tabular}

'Medium, <72 d to midbloom; late, $>72$ d to midbloom. Based on company classification and flowering in Mead irrigated environments.

$(R \approx 0.30-0.50)$ with all RVA parameters measured, except for peak viscosity (Table 4). The hardness parameters of bulk density, true density, and removal by tangential abrasive dehulling device showed moderate correlations $(R \approx 0.30-0.50)$ for most RVA parameters, except for low correlations with peak viscosity and higher correlations with peak time $(R \approx$ 0.60). Almeida-Dominguez et al. (1997) reported that grain density in maize was correlated with low peak viscosities and high peak temperatures and indicated that softer maize grain developed a greater viscosity more rapidly than denser maize 
Table 3. Pearson correlations and probability levels between starch-viscosity properties for grain sorghum.

\begin{tabular}{|c|c|c|c|c|c|c|}
\hline \multirow[b]{2}{*}{ Property } & \multicolumn{5}{|c|}{ Viscosity } & \multirow[b]{2}{*}{ Peak time } \\
\hline & Peak & Trough & Breakdown & Final & Setback & \\
\hline Trough1 & $0.81^{* \star}$ & & & & & \\
\hline Breakdown & $0.84^{\star \star}$ & $0.37^{\star \star}$ & & & & \\
\hline Final viscosity & $0.58^{\star *}$ & $0.81^{\star *}$ & $0.17^{\star \star}$ & & & \\
\hline Setback & $0.42^{\star *}$ & $0.64^{\star \star}$ & 0.07 & $0.97^{* *}$ & & \\
\hline Peak time & $-0.51^{\star \star}$ & -0.03 & $-0.78^{\star \star}$ & $0.09^{\star}$ & $0.12^{\star \star}$ & \\
\hline Pasting temperature & $-0.51^{\star \star}$ & -0.05 & $-0.74^{\star \star}$ & $0.10^{*}$ & $0.15^{\star \star}$ & $0.71^{\star *}$ \\
\hline
\end{tabular}

*Significant at $P \leq 0.05$ level of probability.

${ }^{*}$ Significant at $P \leq 0.01$ level of probability.

Table 4. Pearson correlations and probability levels for yield, kernel mass, hardness, starch, and protein concentrations with starch-viscosity properties for grain sorghum.

\begin{tabular}{|c|c|c|c|c|c|c|c|}
\hline \multirow[b]{2}{*}{ Property } & \multicolumn{5}{|c|}{ Viscosity } & \multirow[b]{2}{*}{ Peak time } & \multirow[b]{2}{*}{$\begin{array}{c}\text { Pasting } \\
\text { temperature }\end{array}$} \\
\hline & Peak & Trough & Breakdown & Final & Setback & & \\
\hline Grain yield $^{\dagger}$ & 0.05 & $0.44^{\star \star}$ & $-0.31^{\star \star}$ & $0.52^{\star *}$ & $0.50^{\star \star}$ & $0.46^{\star \star}$ & $0.40^{\star \star}$ \\
\hline Kernel mass & -0.01 & $0.34^{\star \star}$ & $-0.33^{\star \star}$ & $0.45^{\star \star}$ & $0.44^{\star \star}$ & $0.46^{\star \star}$ & $0.24^{\star *}$ \\
\hline Bulk density & -0.08 & $0.33^{\star *}$ & $-0.42^{\star \star}$ & $0.49^{* *}$ & $0.50^{\star \star}$ & $0.57^{\star *}$ & $0.35^{\star \star}$ \\
\hline True density & $-0.10^{*}$ & $0.32^{* *}$ & $-0.45^{\star *}$ & $0.47^{\star \star}$ & $0.48^{\star *}$ & $0.61^{\star \star}$ & $0.37^{\star \star}$ \\
\hline Removal by tangential abrasive dehulling device & $0.15^{\star \star}$ & $-0.27^{\star \star}$ & $0.48^{\star *}$ & $-0.41^{\star \star}$ & $-0.42^{\star *}$ & $-0.61^{\star \star}$ & -0.39 \\
\hline Protein & $-0.69^{* *}$ & -0.50 & $-0.63^{\star \star}$ & $-0.37^{\star \star}$ & $-0.28^{\star \star}$ & $0.50^{* *}$ & $0.44^{* *}$ \\
\hline Starch & $0.38^{* *}$ & $0.55^{\star \star}$ & $0.10^{*}$ & $0.59^{\star *}$ & $0.54^{\star \star}$ & $0.15^{\star \star}$ & -0.02 \\
\hline
\end{tabular}

*Significant at $\mathrm{P} \leq 0.05$ level of probability.

${ }^{*}$ Significant at $P \leq 0.01$ level of probability.

${ }^{\dagger}$ Grain yield, kernel mass, bulk density, true density, and removal by tangential abrasive dehulling device were previously reported in Griess et al., 2010.

grain. In dense kernels a protein matrix surrounds the starch, so starch hydration is slow, and thus the final and setback viscosities are lower due to fewer starch molecules being released from granules compared with softer kernels. Protein concentration was moderately correlated with most RVA parameters but had higher correlations with peak, breakdown, and trough viscosities and peak time. In contrast, starch concentration was not associated with pasting temperature, since pasting temperature is related to the internal starch structure of starch granules instead of to the starch concentration (Narváez-González et al., 2007). Starch concentration had relatively high correlations with final, trough, and setback viscosities, in contrast with the results of Barbosa Pinto et al. (2009). Beta et al. (2000) reported that peak viscosity for sorghum starch was positively correlated with breakdown and negatively correlated with setback viscosities, whereas setback viscosity was negatively correlated with peak viscosity and positively correlated with final viscosity. In that study, the textural hardness of gels was positively correlated with final and setback viscosity and negatively correlated with peak and breakdown viscosities.

\section{Analysis of Variance}

Mean squares in the ANOVA indicated that environment, hybrid, and environment-by-hybrid-interaction effects were significant for all RVA parameters. However, the environment accounted for $71-85 \%$ of the total variation, the hybrid accounted for $11-23 \%$, and the environmentby-hybrid interaction for only 1-3\% (Table 5). Rhymer et al. (2005) found similar results for RVA analysis of oat (Avena sativa L.) flour. Therefore, this paper will focus on the main effects of the environment and hybrid.

\section{Environment}

Protein concentrations were greater in more stressful production environments (i.e., low $\mathrm{N}$ and limited water), while starch concentrations were higher in less-stressful production environments (i.e., adequate $\mathrm{N}$, irrigated) (Tables 1 and 6), results that were consistent with the expected inverse relationships between protein concentration and starch (Barbosa Pinto et al., 2009).

Identifying environments producing grain with consistent cooking and pasting properties would require food processors to make only minor adjustments to maximize the quality of the final product (Tester and Karkalas, 2001). All viscosity parameters and pasting temperatures of grain had a wide range across environments, whereas the variation in peak time was less (Table 1). The peak and breakdown viscosities were greater for grain produced in 2004 than in 2005, while all other RVA parameters were greater for grain produced in 2005 (Table 6). The 2005 growing season had higher temperatures and potential evaporations than 2004 and low rainfall during the month of August, and produced denser grain (Griess et al., 2010), and starch concentrations were lower. The peak and trough viscosities, the pasting temperature, and the starch concentration of grain were greater under irrigated 
Table 5. Degrees of freedom and mean squares for environment and hybrid effects on sorghum protein and starch concentrations and starch-viscosity properties.

\begin{tabular}{|c|c|c|c|c|c|c|c|c|c|c|}
\hline \multirow[b]{2}{*}{ Source } & \multirow[b]{2}{*}{ df } & \multirow[b]{2}{*}{ Starch } & \multirow[b]{2}{*}{ Protein } & \multicolumn{5}{|c|}{ Viscosity } & \multirow[b]{2}{*}{$\begin{array}{l}\text { Peak } \\
\text { time }\end{array}$} & \multirow[b]{2}{*}{$\begin{array}{c}\text { Pasting } \\
\text { temperature }\end{array}$} \\
\hline & & & & Peak & Trough & Breakdown & Final & Setback & & \\
\hline Environment & 11 & $14,324^{\star *}$ & $6312^{\star \star}$ & $2752730^{\star \star}$ & $1084390^{\star \star}$ & $1189668^{\star \star}$ & $11552074^{\star \star}$ & $6725708^{\star \star}$ & $8.1024^{\star \star}$ & $163.388^{\star \star}$ \\
\hline Error A & 24 & 297 & 325 & 113416 & 39512 & 32562 & 290572 & 190288 & 0.1648 & 5.897 \\
\hline Hybrid & 15 & $1751^{\star \star}$ & $899^{\star \star}$ & $714940^{* *}$ & $145804^{\star \star}$ & $298381^{\star *}$ & $2217094^{\star \star}$ & $1402936^{\star \star}$ & $1.1964^{\star \star}$ & $52.262^{\star \star}$ \\
\hline Environment by hybrid & 165 & $203^{\star \star}$ & $67^{\star \star}$ & $116791^{\star *}$ & $30578^{\star \star}$ & $44715^{\star \star}$ & $245220^{\star *}$ & $140269^{\star \star}$ & $0.0882^{\star \star}$ & $5.687^{\star \star}$ \\
\hline $\begin{array}{l}\text { Food-grade vs. non- } \\
\text { food-grade }\end{array}$ & 11 & 140 & $67^{*}$ & $76791^{\star}$ & 19052 & 28316 & $252889^{* *}$ & $179941^{* *}$ & 0.0860 & $5.5044^{*}$ \\
\hline $\begin{array}{l}\text { Medium vs. late } \\
\text { maturity }\end{array}$ & 11 & 122 & $72^{*}$ & 5285 & 10449 & $28528^{*}$ & 61406 & 45102 & 0.0917 & $6.7626^{\star}$ \\
\hline Residual & $353-358^{+}$ & 121 & 37 & 26814 & 10374 & 8880 & 56442 & 27100 & 0.0399 & 2.169 \\
\hline
\end{tabular}

*Significant at $P \leq 0.05$ level of probability.

${ }^{*}$ Significant at $P \leq 0.01$ level of probability.

${ }^{\dagger}$ Residual df varied due to limited grain mass from some plots making it impossible to conduct all quality tests. These were treated as missing plots.

Table 6. Environment contrast comparisons for protein and starch concentrations and starch-viscosity properties of sorghum grain.

\begin{tabular}{|c|c|c|c|c|c|c|c|c|c|}
\hline \multirow[b]{2}{*}{ Contrast comparisons } & \multirow[b]{2}{*}{ Protein } & \multirow[b]{2}{*}{ Starch } & \multicolumn{5}{|c|}{ Viscosity } & \multirow[b]{2}{*}{ Peak time } & \multirow[b]{2}{*}{$\begin{array}{c}\text { Pasting } \\
\text { temperature }\end{array}$} \\
\hline & & & Peak & Trough & Breakdown & Final & Setback & & \\
\hline & \multicolumn{2}{|c|}{$\mathrm{g} \mathrm{kg}^{-1}$} & & & $\mathrm{CP}$ & & & $\min$ & ${ }^{\circ} \mathrm{C}$ \\
\hline 2004 & 103 & 689 & 1597 & 1151 & 445 & 3097 & 1946 & 10.48 & 86.12 \\
\hline 2005 & 99 & 703 & 1514 & 1203 & 310 & 3519 & 2316 & 10.93 & 87.25 \\
\hline$P$-value & NS & $<0.01$ & 0.01 & 0.01 & $<0.01$ & $<0.01$ & $<0.01$ & $<0.01$ & $<0.01$ \\
\hline Irrigated & 106 & 701 & 1533 & 1191 & 289 & 3534 & 2242 & 10.83 & 88.26 \\
\hline Dryland & 107 & 697 & 1435 & 1180 & 281 & 3375 & 2291 & 11.02 & 87.04 \\
\hline$P$-value & NS & 0.05 & $<0.01$ & $<0.01$ & NS & NS & 0.02 & $<0.01$ & $<0.01$ \\
\hline Mead & 105 & 701 & 1468 & 1218 & 250 & 3397 & 2179 & 11.06 & 88.30 \\
\hline Clay Center & 103 & 703 & 1542 & 1219 & 323 & 3680 & 2461 & 10.83 & 87.61 \\
\hline$P$-value & NS & NS & $<0.01$ & NS & $>0.01$ & $<0.01$ & $<0.01$ & $<0.01$ & $<0.01$ \\
\hline Dryland Clay Center & 106 & 695 & 1365 & 1068 & 369 & 3227 & 2159 & 10.80 & 86.96 \\
\hline Hebron & 99 & 699 & 1682 & 1268 & 413 & 3568 & 2300 & 10.78 & 86.39 \\
\hline$P$-value & 0.02 & NS & $<0.01$ & $<0.01$ & $<0.01$ & 0.03 & $<0.01$ & NS & NS \\
\hline 2005 Orleans & 125 & 688 & 1040 & 924 & 116 & 2521 & 1597 & 11.19 & 86.32 \\
\hline Other locations & 103 & 699 & 1445 & 1189 & 257 & 3703 & 2514 & 10.97 & 87.67 \\
\hline$P$-value & $<0.01$ & $<0.01$ & $<0.01$ & $<0.01$ & $<0.01$ & $<0.01$ & $<0.01$ & $<0.01$ & $<0.01$ \\
\hline
\end{tabular}

than under dryland water regimes, consistent with the results of Taylor et al. (1997).

The Orleans (2005) environment, the most water-stressful environment, produced grain with high protein and low starch concentrations, the lowest peak, trough, breakdown, final, and setback viscosities, and relatively high peak time and intermediate pasting temperature (Tables 1 and 6; Fig. 1D); it also produced the densest grain (Griess et al., 2010). These results indicated that starch granules in the flour from this environment hydrated more slowly (due to the thick protein matrix surrounding the starch granules) and took longer to gelatinize, that the flour slurry was less stable during shear-force thinning, and that the aligned starch molecules did not reassociate well with each other. Grain produced in this environment would therefore be well suited for food products made by dry milling (Johnson, 2005) and alkaline cooking (Almeida-Dominguez et al., 1997; Johnson et al., 2010).

In contrast, the Hebron dryland 2004, Clay Center irrigated 2004, and Mead dryland low-N 2005 environments produced grain with the highest peak, trough, breakdown, and final viscosities and high setback viscosities (Table 1; Fig. 1B). These environments produced grain with low protein concentrations. In addition, grain from the Mead dryland low-N 2005 environment had high starch concentrations. Pasting temperatures were low for grain produced in Hebron dryland 2004 and Mead dryland low-N 2005 environments, and the Clay Center irrigated 2004 environment had the lowest breakdown viscosity. The Hebron dryland environment produced soft kernels (Griess et al., 2010), and the Mead dryland low-N 2005 environment produced grain with low protein and high starch concentrations. These results suggest that these three environments produced grain useful for processed and canned products (Beta et al., 2000), porridge (Taylor et al., 1997), ethanol (Wu et al., 2007; Zhao et al., 2008), and/or consumable alcohol (Agu and Palmer, 1998; Agu et al., 2006).

The Clay Center irrigated 2005 environment produced the highest grain yield (Griess et al., 2010), grain with low protein and intermediate starch concentrations, and 


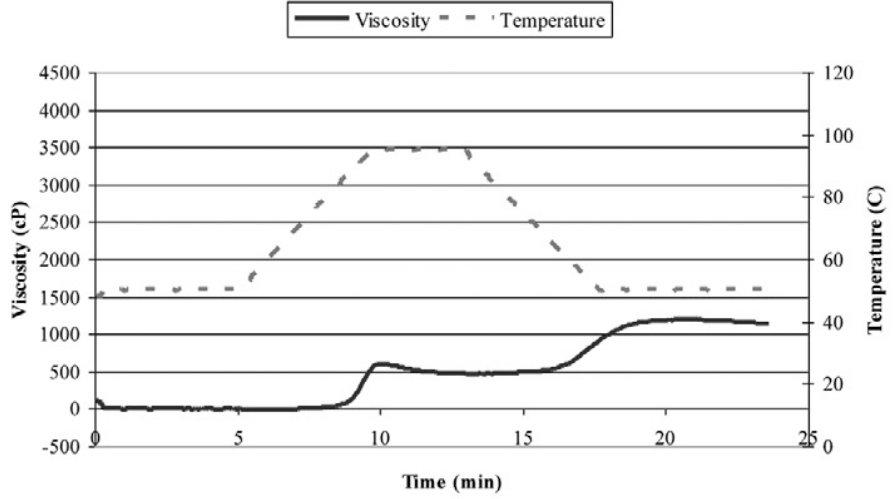

B. Mead Dryland with Low N 2005 (High Starch)

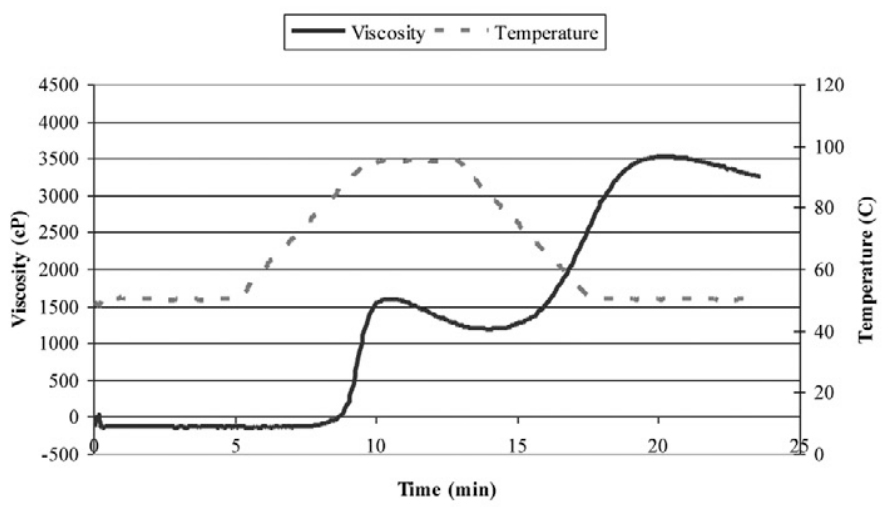

C. Clay Center Irrigated 2005 (High Yield)

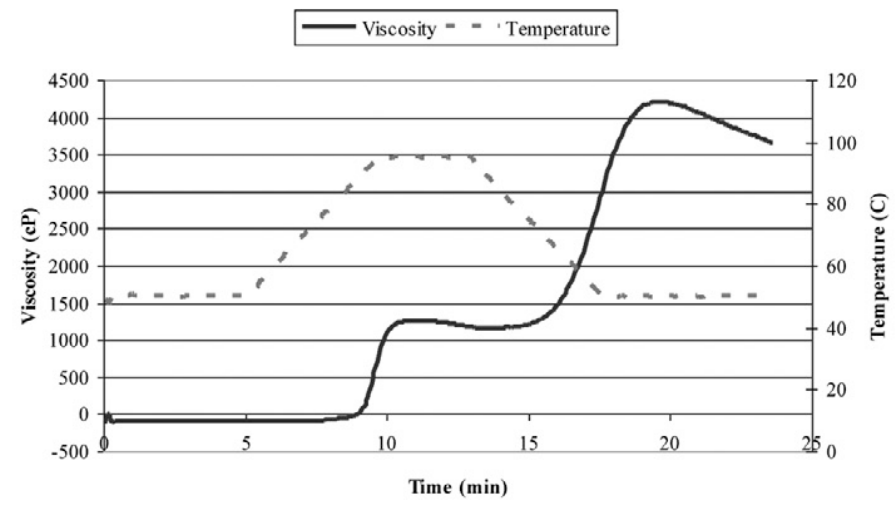

D. Orleans Dryland 2005 (Hard Kernels)

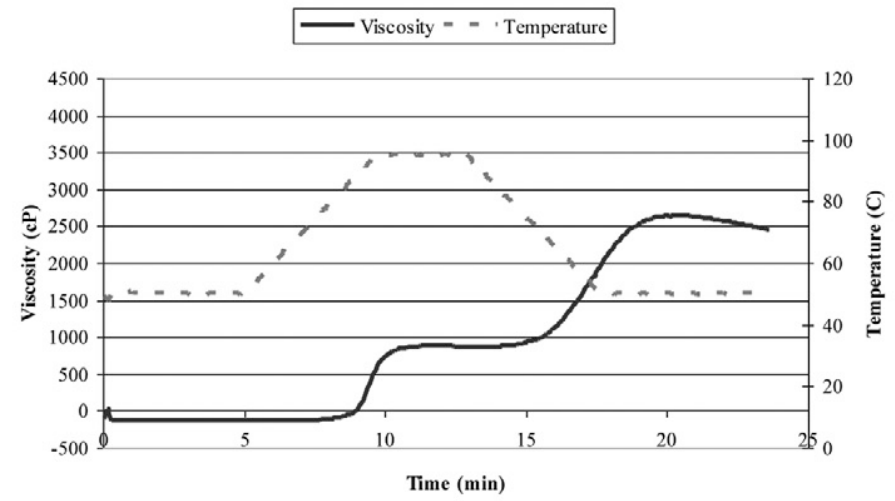

Figure 1. Rapid-visco-analysis profiles for Macia in contrasting environments based on grain yield, kernel density, and starch concentration.

intermediate values for all RVA parameters measured (Tables 1 and 6; Fig. 1C). Irrigated environments in both years, and several dryland environments in the higher rainfall 2005 growing season, also produced grain with intermediate RVA values. Irrigated environments and dryland environments in 2005 produced grain with high pasting temperatures.

The Mead dryland low-N environments had a combination of water and $\mathrm{N}$ stress, with the $\mathrm{N}$ stress being much more severe in 2004 than in 2005. In both years the Mead dryland low-N environments produced grain that had the highest breakdown viscosities, whereas in 2004 this environment also produced the lowest trough, final, and setback viscosities, low peak time and pasting temperature (Table 1; Fig. 1B), and the softest grain (Griess et al., 2010). Grain produced in the Mead dryland low-N 2004 environment was of very poor quality for all common end uses.

\section{Hybrid Main Effects}

Protein concentrations of food-grade and non-food-grade hybrids were similar, whereas the food-grade variety, Macia, had higher protein concentration than the foodgrade hybrids (Tables 7 and 8). Medium-maturity hybrids had slightly higher protein concentrations than late-maturity hybrids, which was partially associated with $0.4 \mathrm{Mg}$ $\mathrm{ha}^{-1}$ lower grain yields (Griess et al., 2010). Duvick (2005) also reported a similar relationship between grain yield and protein concentration. Starch concentrations were slightly greater in the grain of food-grade hybrids, while the maturity classification had little effect (Table 8 ). Although the average was similar, food-grade hybrids had a wider range of protein and starch concentrations than among non-foodgrade hybrids (Table 7), thus high protein or starch concentrations could be achieved by selecting the best hybrids. In most cases, an inverse relationship between protein and starch concentrations appeared to be present, as expected (Barbosa Pinto et al., 2009). Food-grade hybrids with high amounts of starch and low amounts of protein that could be converted to fermentable sugars would be desirable to brewers (Agu and Palmer, 1998).

The range of hybrid differences for RVA viscosities (Table 7) was less than the range of environment differences (Table 1). On average, food-grade hybrids had higher peak and breakdown viscosities (Table 8), and the food-grade check variety Macia, which produced dense kernels across environments (Griess et al., 2010), had lower values for all RVA viscosities (Tables 7 and 8; Fig. 2A). Maturity classification had little to no influence on starch viscosity parameters (Table 8).

The results of RVA analysis allowed food-grade sorghums to be clustered into three groups. The viscosities for Macia, Asgrow Orbit, and Sorghum Partners NK1486 were similar (Table 7; Fig. 2B). They had low peak, trough, breakdown, and final viscosities with high peak 
Table 7. Influence of hybrid on protein and starch concentrations and starch-viscosity properties of grain sorghum (averaged over 12 environments).

\begin{tabular}{|c|c|c|c|c|c|c|c|c|c|}
\hline \multirow[b]{2}{*}{ Hybrid } & \multirow[b]{2}{*}{ Protein } & \multirow[b]{2}{*}{ Starch } & \multicolumn{5}{|c|}{ Viscosity } & \multirow[b]{2}{*}{$\begin{array}{l}\text { Peak } \\
\text { time }\end{array}$} & \multirow[b]{2}{*}{$\begin{array}{c}\text { Pasting } \\
\text { temperature }\end{array}$} \\
\hline & & & Peak & Trough & Breakdown & Final & Setback & & \\
\hline Food-grade & \multicolumn{2}{|c|}{$\mathrm{g} \mathrm{kg}^{-1}$} & 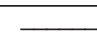 & 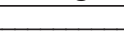 & $\mathrm{cP}$ & 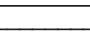 & + & $\min$ & ${ }^{\circ} \mathrm{C}$ \\
\hline Sorghum Partners NK 8828 & 107 & 685 & 1485 & 1055 & 431 & 2511 & 1556 & 10.58 & 85.78 \\
\hline Asgrow Eclipse & 100 & 703 & 1651 & 1237 & 414 & 3612 & 2375 & 10.74 & 86.76 \\
\hline Asgrow Orbit & 111 & 690 & 1324 & 1041 & 284 & 3168 & 2127 & 10.81 & 88.23 \\
\hline Kelly Green Seed KG6902 & 97 & 705 & 1678 & 1234 & 444 & 3497 & 2262 & 10.58 & 85.36 \\
\hline Fontanelle W-1000 & 95 & 707 & 1651 & 1210 & 441 & 3475 & 2265 & 10.57 & 84.56 \\
\hline NC+ Hybrids 7W92 & 97 & 703 & 1682 & 1224 & 458 & 3441 & 2217 & 10.51 & 85.17 \\
\hline Sorghum Partners NK 1486 & 112 & 684 & 1326 & 1094 & 232 & 3158 & 2064 & 10.98 & 88.40 \\
\hline Dekalb 44-41 & 104 & 696 & 1587 & 1211 & 377 & 3453 & 2242 & 10.71 & 87.09 \\
\hline Mycogen 14665 & 97 & 701 & 1354 & 1102 & 252 & 3167 & 2065 & 10.94 & 87.39 \\
\hline Mean & & & 1526 & 1156 & 370 & 3286 & 2130 & 10.72 & 86.53 \\
\hline Food-grade check (Macia) & 107 & 685 & 1241 & 1083 & 158 & 2892 & 1809 & 11.11 & 87.58 \\
\hline \multicolumn{10}{|l|}{ Non-food-grade (checks) } \\
\hline Dekalb 54-00 & 105 & 694 & 1445 & 1159 & 285 & 3233 & 2073 & 10.93 & 86.94 \\
\hline Dekalb 42-20 & 103 & 695 & 1447 & 1145 & 302 & 3415 & 2270 & 10.91 & 87.81 \\
\hline Dekalb 53-11 & 104 & 699 & 1583 & 1205 & 378 & 3353 & 2148 & 10.67 & 85.60 \\
\hline NC+ Hybrids 6 C69 & 105 & 696 & 1417 & 1153 & 264 & 3273 & 2120 & 11.00 & 88.29 \\
\hline Pioneer 84Y00 & 101 & 693 & 1520 & 1172 & 348 & 3368 & 2195 & 10.64 & 85.84 \\
\hline Mycogen 3696 & 101 & 692 & 1629 & 1204 & 425 & 3422 & 2218 & 10.68 & 86.75 \\
\hline Mean & & & 1507 & 1173 & 334 & 3344 & 2171 & 10.81 & 86.87 \\
\hline LSD (0.05) & 3 & 5 & 76 & 47 & 44 & 110 & 76 & 0.09 & 0.68 \\
\hline
\end{tabular}

time and pasting temperatures. These results indicate that the starch granules in the flour hydrated more slowly and took longer to gelatinize, that the flour slurry was less stable when exposed to shear, and that aligned starch molecules did not reassociate well with each other. Grain from these hybrids would likely be well suited for food products made by dry milling (Johnson, 2005) or alkaline cooking (Almeida-Dominguez et al., 1997; Johnson et al., 2010).

Food-grade hybrids with high peak, trough, breakdown, and final viscosities and low peak time and pasting temperature were NC+ Hybrids 7W92, Kelly Green Seed KG6902, Asgrow Eclipse, and Fontanelle W-1000 (Table 7; Fig. 2C). Flour from grain produced by these hybrids hydrated quickly to produce high peak viscosities and dispersed starch molecules during shear thinning, which then became highly aligned and could therefore result in gels that had increased stability, as indicated by high final and setback viscosities. Grain from these hybrids was soft (Griess et al., 2010) and had lower protein and higher starch concentrations (Table 1), suggesting that these hybrids would

Table 8. Hybrid contrast comparisons for protein and starch concentrations and starch-viscosity properties of sorghum.

\begin{tabular}{|c|c|c|c|c|c|c|c|c|c|}
\hline \multirow[b]{2}{*}{ Contrast comparisons } & \multirow[b]{2}{*}{ Protein } & \multirow[b]{2}{*}{ Starch } & \multicolumn{5}{|c|}{ Viscosity } & \multirow[b]{2}{*}{ Peak time } & \multirow{2}{*}{$\begin{array}{c}\text { Pasting } \\
\text { temperature }\end{array}$} \\
\hline & & & Peak & Trough & Breakdown & Final & Setback & & \\
\hline & \multicolumn{2}{|c|}{$\mathrm{g} \mathrm{kg}^{-1}$} & & & $\mathrm{CP}$ & & - & $\min$ & ${ }^{\circ} \mathrm{C}$ \\
\hline Food-grade hybrids & 102 & 697 & 1526 & 1156 & 370 & 3286 & 2130 & 10.72 & 86.53 \\
\hline Check hybrids & 103 & 695 & 1507 & 1173 & 334 & 3344 & 2171 & 10.81 & 86.87 \\
\hline$P$-value & NS & $<0.01$ & NS & NS & $<0.01$ & 0.02 & 0.03 & $<0.01$ & 0.01 \\
\hline Food-grade hybrids & 102 & 697 & 1526 & 1156 & 370 & 3286 & 2130 & 10.72 & 86.53 \\
\hline Food-grade check (Macia) & 107 & 685 & 1241 & 1083 & 158 & 2892 & 1809 & 11.11 & 87.58 \\
\hline$P$-value & $<0.01$ & $<0.01$ & $<0.01$ & $<0.01$ & $<0.01$ & $<0.01$ & $<0.01$ & $<0.01$ & $<0.01$ \\
\hline Medium & 103 & 697 & 1530 & 1172 & 332 & 3377 & 2205 & 10.76 & 86.86 \\
\hline Late maturity & 101 & 696 & 1496 & 1144 & 352 & 3175 & 2030 & 10.73 & 86.26 \\
\hline$P$-value & $<0.01$ & NS & 0.04 & $<0.01$ & NS & $<0.01$ & $<0.01$ & NS & $<0.01$ \\
\hline Medium, food-grade hybrids & 103 & 697 & 1537 & 1169 & 368 & 3384 & 2215 & 10.72 & 86.70 \\
\hline Late -maturity, food-grade hybrid & 100 & 697 & 1506 & 1130 & 375 & 3091 & 1961 & 10.70 & 86.17 \\
\hline$P$-value & $<0.01$ & NS & NS & $<0.01$ & NS & $<0.01$ & $<0.01$ & NS & $<0.01$ \\
\hline Medium, non-food-grade hybrids & 103 & 696 & 1519 & 1177 & 342 & 3365 & 2119 & 10.82 & 87.09 \\
\hline Late, non-good-grade hybrids & 103 & 694 & 1482 & 1166 & 317 & 3300 & 2134 & 10.79 & 86.39 \\
\hline$P$-value & NS & 0.05 & NS & NS & NS & $<0.01$ & $<0.01$ & NS & $<0.01$ \\
\hline
\end{tabular}



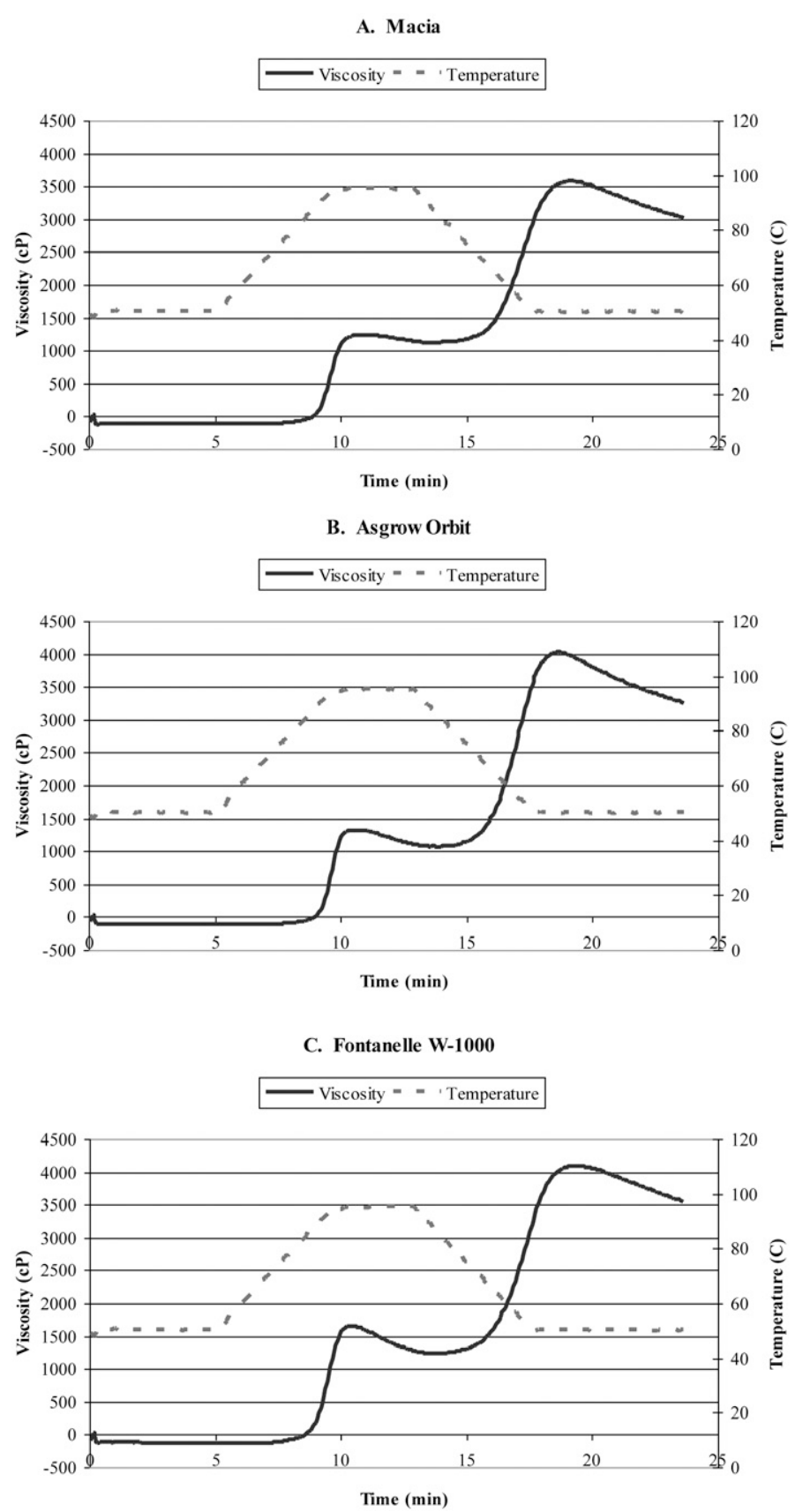

Figure 2. Rapid-visco-analysis profiles for (A) Macia, (B) Asgrow Orbit, and (C) Fontanelle W-1000 averaged over 12 environments.

be useful in canned-food (Beta et al., 2000), porridge (Taylor et al., 1997), ethanol (Wu et al., 2007; Zhao et al., 2008), and consumable-alcohol production (Agu and Palmer, 1998; Agu et al., 2006). The viscosities for other food-grade and non-food-grade hybrids were intermediate.

\section{Environment-by-Hybrid Interaction}

The effect of the environment-by-hybrid interaction composed $3 \%$ or less of the total variation for all RVA parameters measured (Table 5). Partitioning of the interaction effect indicated that hybrid maturity had little effect, whereas minor differences were present between food-grade and non-foodgrade hybrids for peak, final, and setback viscosities and pasting temperature. These viscosities and pasting temperature increased as the environment means increased, with slopes close to 1 (ranging from 0.98 to 1.08; Fig. 3), in contrast to food processors' preference for stable grain quality (i.e., slopes $<1$ ), which give similar starch viscosity response during processing. The peak viscosity was greater for food-grade hybrids when environmental means were low but was greater for non-foodgrade hybrids when environmental means were high (Fig. 3A). The final and setback viscosities and pasting temperature were always higher for non-food grade hybrids than for food grade hybrids, and the difference was small and nearly constant across the environmental means (Fig. 3B, 3C, and 3D).

\section{CONCLUSION}

The environment in which sorghum is produced clearly has a greater influence on RVA starch-viscosity properties of sorghum grain than does hybrid selection or hybridby-environment interactions. Unfortunately, these results suggest that it is difficult to predict the effect that environment will have on resulting starch viscosity properties since similar environments (as defined by location, water availability, and $\mathrm{N}$ stress) resulted in variable sorghum RVA starch properties. Additional information on the effect of environment on resulting sorghum-starch properties will be needed to build reliable predictive models.

Although of secondary importance in terms of total variation in sorghum-starch RVA properties, the choice of hybrid predictably and significantly contributes to sorghum-starch viscosity properties. RVA analysis clearly indicated that grain and glume color (the de facto definitive parameters of food-grade sorghum) are not the only important properties defining grain quality in food-grade sorghum. Food-grade sorghum hybrids were grouped based on viscosity properties into those best suited for dry-mill and alkaline-cooked products (Asgrow Orbit, Sorghum Partners NK1486) and those best suited for porridge, consumable alcohol and ethanol production (Kelly Green KG6902, NC+ Hybrids 7W92, Asgrow Eclipse and Fontanelle W-1000). There results were consistent with those previously reported for grain density, and protein and starch concentrations (Griess et al., 2010).

\section{References}

Agu, R.C., T.A. Gringhurst, and J.M. Brosnan. 2006. Production of grain whisky and ethanol from wheat, maize and other cereals. J. Inst. Brew. 112:314-323.

Agu, R.C., and G.H. Palmer. 1998. A reassessment of sorghum for lager-beer brewing. Bioresour. Technol. 66:253-261.

Almeida-Dominguez, H.D., E.L. Suhendro, and L.W. Rooney. 1997. Factors affecting rapid visco analyser curves for the determination of maize kernel hardness. J. Cereal Sci. 25:93-102.

Barbosa Pinto, A.T., J. Pereira, T. Roselena de Oliveira, R. Aparecida Prestes, R. Rodrigues Mattielo, and I. Mottin Demiate. 2009. Characterization of corn landraces planted grown in the Campos Gerais region (Paraná, Brazil) for industrial utilization. Braz. Arch. Biol. Technol. 52:17-28. 
A. Peak Viscosity

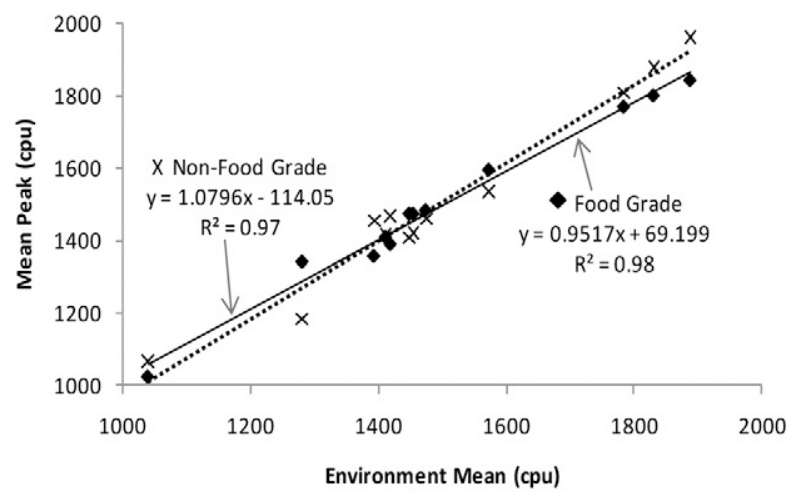

B. Final Viscosity

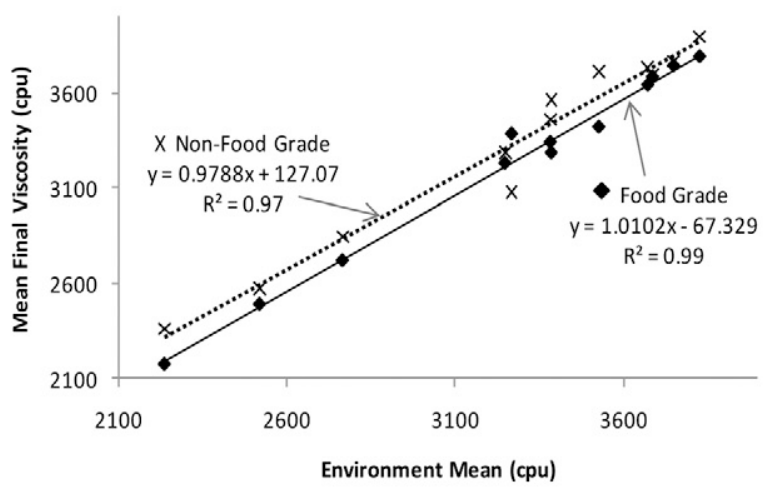

C. Viscosity

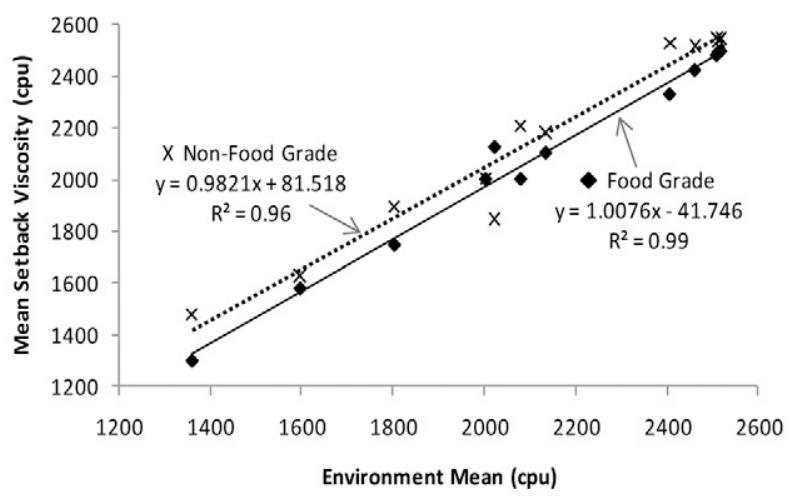

D. Pasting Temperature

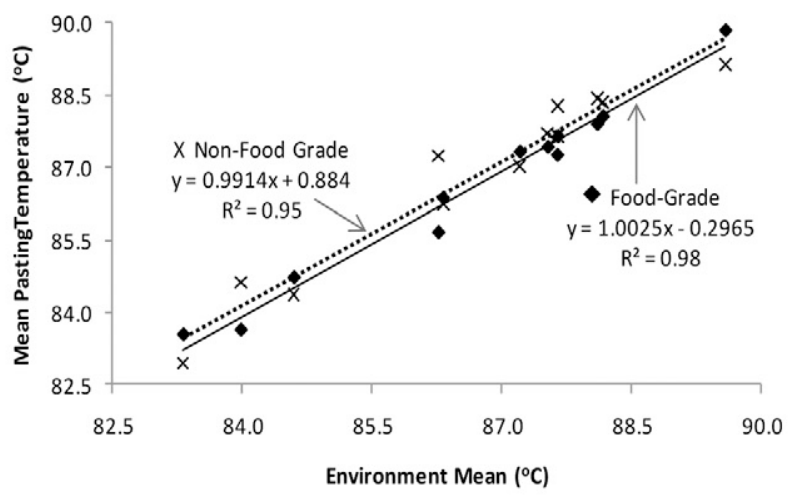

Figure 3. Influence of food-grade and non-food-grade hybrids on starch-viscosity properties across environments.

Beta, T., and H. Corke. 2001. Noodle quality as related to sorghum starch properties. Cereal Chem. 78:417-420.

Beta, T., H. Corke, L.W. Rooney, and J.R.N. Taylor. 2000. Starch properties as affected by sorghum grain chemistry. J. Sci. Food Agric. 81:245-251.

Beta, T., A. Babatunde Obilana, and H. Corke. 2001. Genetic diversity in starch properties from Zimbabwean sorghum landraces. Cereal Chem. 78:583-589.

Budak, N., P.S. Baenziger, K.M. Eskridge, D. Baltensperger, and B. Moreno-Sevilla. 1995. Plant height response of semidwarf and nonsemidwarf wheats to environment. Crop Sci. 35:447-451.

Deffenbaugh, L.B., and C.E. Walker. 1989. Comparison of starch pasting properties in the Brabender Viscoamylograph and the Rapid Visco-Analyzer. Cereal Chem. 66:493-499.

Dlamini, N.R., J.R.N. Taylor, and L.W. Rooney. 2007. The effect of sorghum type and processing on the antioxidant properties of African sorghum-based foods. Food Chem. 105:1412-1419.

Duvick, D.N. 2005. The contribution of breeding to yield advances in maize (Zea mays L.). Adv. Agron. 86:83-145.

Fasano, A., and C. Catassi. 2001. Current approaches to diagnosis and treatment of celiac disease: An evolving spectrum. Gastroenterology 120:636-651.

Figueroa, J.D.C., B.F. Martinez, and E. Rios. 1995. Effect of sorghum endosperm type on the quality of adjuncts for the brewing industry. J. Am. Soc. Brew. Chem. 53:5-9.

Fox, G., and M. Manley. 2009. Hardness methods for testing maize kernels. J. Agric. Food Chem. 57:5647-5657.

Gomez, M.H., J.K. Lee, C.M. McDonough, R.D. Waniska, and L.W. Rooney. 1992. Corn starch changes during tortilla and tortilla chip processing. Cereal Chem. 69:275-279.

Griess, J.K., S.C. Mason, D.S. Jackson, T.D. Galusha, M. Yaseen, and J.F. Pederson. 2010. Environment and hybrid influences on food-grade sorghum grain yield and hardness. Crop Sci. 50:1480-1489.

Hall, M.B. Factors affecting starch analysis of feeds. 2001. Inst. Food Agric. Sci. Publ. no. AS121. Univ. of Florida, Gainesville, FL.

Hattendorf, M.J., M.S. Redelfs, B. Amos, L.R. Stone, and R.E.J. Gwin. 1988. Comparative water use characteristics of six row crops. Agron. J. 80:80-85.

Johnson, W.B. 2005. The influence of corn and sorghum characteristics on wet milling and nixtamalization performance. M.S. thesis, Univ. of Nebraska, Lincoln, NE.

Johnson, W.B., W.S. Ratnayake, D.S. Jackson, K. Lee, T.J. Herrman, S.R. Bean, and S.C. Mason. 2010. Factors affecting the alkaline cooking performance of selected corn and sorghum hybrids. Cereal Chem. 87:524-531.

Kaye, N.M., S.C. Mason, D.S. Jackson, and T.D. Galusha. 2007. Crop rotation and soil amendment alters sorghum grain quality. Crop Sci. 47:722-729.

Kriegshauser, T.D., J.D. Hancock, and M.R. Tunistra. 2006. Variation in nutritional value of sorghum hybrids with contrasting seed weight characteristics and comparisons with maize in broiler chicks. Crop Sci. 46:695-699.

Maranville, J.W., R.B. Clark, and W.M. Ross. 1980. Nitrogen use efficiency in grain sorghum. J. Plant Nutr. 2:577-589.

Narváez-González, E.D., J.D.F. Cárdenas, S. Taba, E.C. Tostado, and R.A.M. Peniche. 2007. Effect of starch granule size on 
the thermal and pasting properties of maize. Rev. Fitotec. Mex. 30:269-277.

Narváez-González, E.D., J.D. Figueroa-Cárdenas, S. Taba, and F. Rincón Sánchez. 2006. Kernel microstructure of Latin American races of maize and their thermal and rheological properties. Cereal Chem. 83:605-610.

Padmore, J.M. 1990. Protein (crude) in animal feed-Dumas method, method no. 968.06. p. 71-72. In K. Herlich (ed.) Official methods of analysis of the Association of Official Analytical Chemists, AOAC, Int., Arlington, VA.

Ragaee, S., and E.M. Abdel-Aal. 2006. Pasting properties of starch and protein in selected cereals and quality of their food products. Food Chem. 95:9-18.

Rhymer, C., N. Ames, L. Malcolmson, D. Brown, and S. Duguid. 2005. Effects of genotype and environment on the starch properties and end-product quality of oats. Cereal Chem. 82:197-203.

Rooney, L.W. 1996. Attributes of improved quality sorghums for value-added marketing, p. 112-124. In D. Wilkinson (ed.) Proc. Ann. Corn Sorghum Res. Conf., 51th, Chicago. 10-11 Dec. 1996, Amer. Seed Trade Assoc., Washington, DC.
Rooney, L.W., and J.M. Awika. 2005. Overview of products and health benefits of specialty sorghums. Cereal Foods World 50:109-115.

Taylor, F.R.N., J. Dewar, J. Taylor, and R.F. von Ascheraden. 1997. Factors affecting the porridge-making quality of South African sorghums. J. Sci. Food Agric. 73:464-470.

Tester, R.F., and J. Karkalas. 2001. The effects of environmental conditions on the structural features and physico-chemical properties of starches. Starch/Starke 53:513-519.

Walker, C.E., A.S. Ross, C.W. Wrigley, and G.J. McMaster. 1988. Accelerated characterization of starch-paste viscosity and setback with the Rapid Visco-Analyzer. Cereal Foods World 33:491-494.

Wu, X., R. Zhao, S.R. Bean, P.A. Seib, J.S. McLaren, R.L. Madl, M. Tuinstra, M.C. Lenz, and D. Wang. 2007. Factors impacting ethanol production from grain sorghum in the dry-grind process. Cereal Chem. 84:130-136.

Zhao, R., S. Bean, X. Wu, and D. Wang. 2008. Assessing fermentation quality of grain sorghum for fuel ethanol production using rapid visco-analyzer. Cereal Chem. 85:830-836. 